\title{
(5)

\section{Tilrettelegges det godt nok for forskning i legenes spesialistløp?}

LEGELIVET

\section{CECILIE BIRKELI}

LEFO - Legeforskningsinstituttet

I norsk helsetjeneste er mye av det viktigste kunnskapsgrunnlaget basert på forskning.

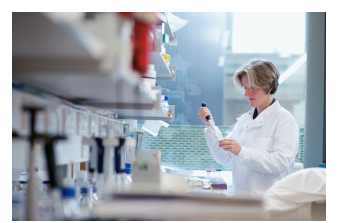

Illustrasjonsfoto: Science Photo

Library

En viktig forutsetning for medisinsk utvikling er at det forskes og at forskningen anvendes $\mathrm{i}$ praksis. Manglende kompetanse her kan bidra negativt i valg av medisiner og behandlingsformer i den daglige pasientbehandlingen (1). Det er i denne forbindelse også viktig å kunne forstå og tolke forskningen - grunnleggende forskningskompetanse er nødvendig for kildekritisk tenkning. Denne kompetansen må læres. Mer overordnet må det legges til rette for og avsettes tilstrekkelig med tid til forskningsprosjekter.

Våren 2017 publiserte LEFO - Legeforskningsinstituttet - resultatene fra Nasjonal evaluering for spesialistutdanningen for leger 2016 (2). Disse viste at $41 \%$ av legene i spesialisering som besvarte spørreskjemaet, svarte nei på om de opplevde at det var lagt til rette for at de skulle kunne drive med forskning på arbeidsplassen sin. På spørsmålet «Opplever du at det er lett å komme i gang med forskningsprosjekter på din arbeidsplass?», svarte $47 \%$ nei. For $23 \%$ ble tiden som var avsatt til forskning, ofte eller svært ofte ble brukt som salderingspost for andre nødvendige oppgaver. Det er derfor et betimelig spørsmål om det tilrettelegges godt nok for at legene skal komme i gang med forskningsprosjekter på arbeidsplassen.

Det har tidligere vært hevdet at forskning ikke prioriteres høyt nok i spesialistutdanningen for leger og at kravene til forskningskompetanse i spesialistutdanningen må defineres tydeligere $(1,3)$. Ifølge dagens regler kan gjennomført forskningstjeneste, for eksempel en ph.d.-grad, telle som en del av spesialistutdanningen (4). Etter den nye spesialistforskriften kan forskning inngå i spesialistløpet innenfor gitte rammer som læringsmålene gir (5). Læringsmålene som omhandler forskning ligger i de såkalte felles kompetansemodulene. Dermed er det så langt opp til helseforetakene hvordan de velger å legge opp løpet videre. 
LITTERATUR:

1. Seljelid R. Forskning og spesialister. Tidsskr Nor Lægeforen 2000; 120: 129. [PubMed]

2. Birkeli CN. Nasjonal evaluering for spesialistutdanningen for leger 2016. Oslo:

Legeforskningsinstituttet, Den norske legeforening, 2017: 27.

3. Nilsen L. - Undervisning av LIS-leger blir brukt som salderingspost. Dagens Medisin 12.6.2017.

https://www.dagensmedisin.no/artikler/2017/06/12/-undervisning-av-lis-leger-blir-brukt-som-saldering spost/ (21.9.2017).

4. Generelle bestemmelser for spesialistutdanning av leger. Oslo: Helsedirektoratet, 2009.

5. Forskrift om spesialistutdanning og spesialistgodkjenning for leger og tannleger

(spesialistforskriften).

https://www.regjeringen.no/no/dokumenter/forskrift-om-spesialistutdanning-og-spesialistgodkjenni ng-for-leger-og-tannleger-spesialistforskriften-og-endringer-i-visse-andre-forskrifter/id2523448/

(21.9.2017).

Publisert:30. oktober 2017. Tidsskr Nor Legeforen. DOI: 10.4045/tidsskr.17.0789

(C) Tidsskrift for Den norske legeforening 2020. Lastet ned fra tidsskriftet.no 